\title{
Technical Efficiency of Growing Sugarcane Crop in Khyber Pakh- tunkhwa, Pakistan
}

\section{Amjad Ali ${ }^{*}$, Lal Almas², Syed Attaullah Shah ${ }^{1}$, Hina Fatima ${ }^{3}$ and Asim Khan ${ }^{1}$}

${ }^{1}$ Department of Agricultural and Applied Economics, The University of Agriculture Peshawar, Khyber Pakhtunkhwa, Pakistan; ${ }^{2}$ Agricultural Business and Economics, West Texas A and M University, Canyon, TX USA; ${ }^{3}$ Muhammad Ali Jinnah University, Karachi, Pakistan.

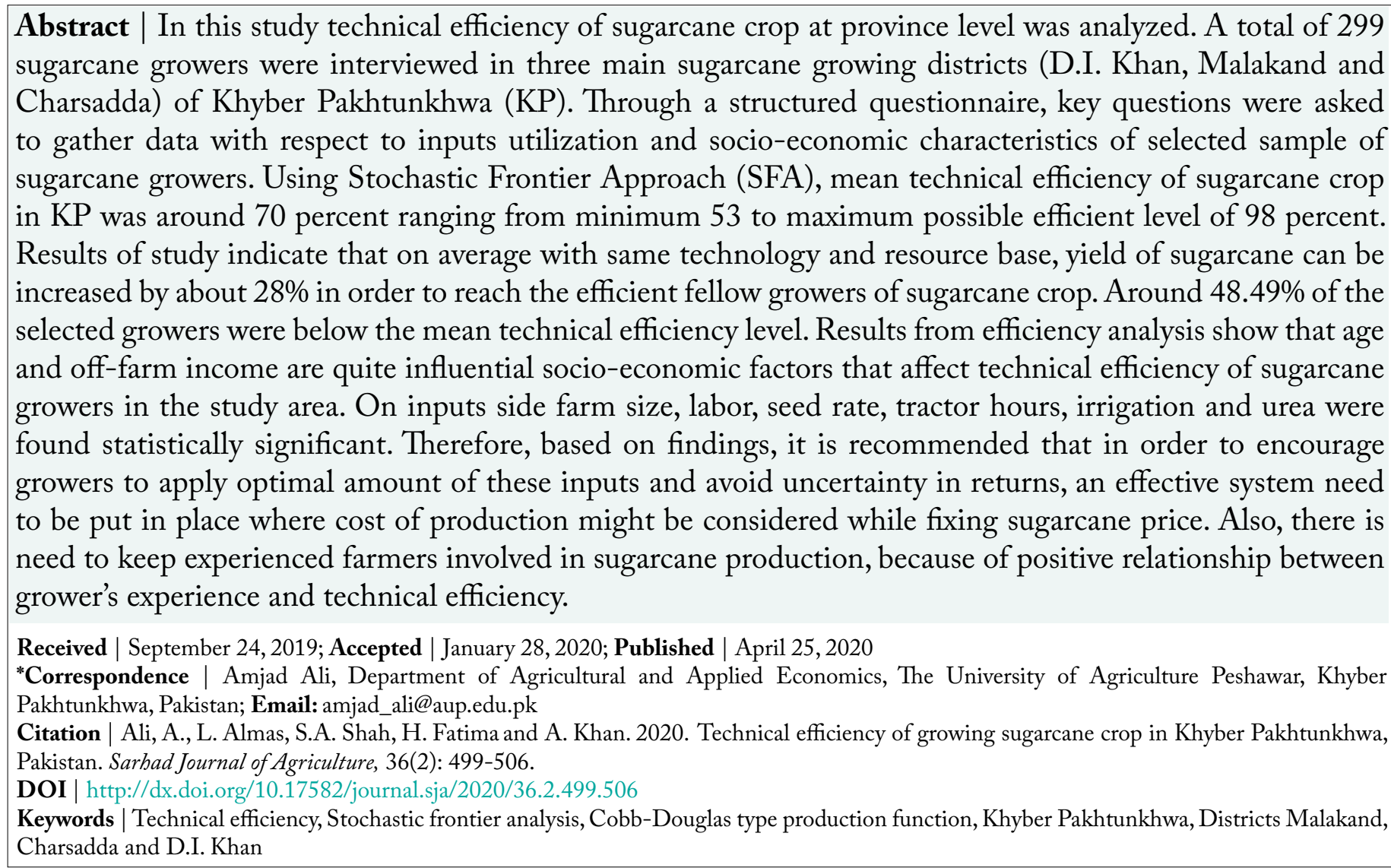

\section{Introduction}

A gricultural sector continues to dominate the economic scene of Pakistan, it account, for 19.8 percent of the Gross Domestic Product (GDP); absorbs $38 \%$ of total labor force and also earns foreign exchange. It has established forward and backward linkages with other sectors of the economy. According to economic development literature, accelerated economic growth needs sustained development of agricultural sector. In agricultural economy of Pakistan sugarcane is a major crop. It contributes in more than one dimensions. Sugarcane is second industrial crop after cotton which employ about 8.76 million people in its production and processing. Indirectly, several others agro and sugar related industries business are linked with this crop (Rizvi, 2000). Its production in Pakistan is managed by private producers. However, June 2020 | Volume 36 | Issue 2 | Page 499 
its marketing has mainly been regulated or managed by the government in one or the other way (ACTP, 2001-2002; Scott et al., 1990). Unlike other crops, sugarcane is not imported into nor exported from Pakistan. Out of total produce, $85 \%$ goes to sugar mills, being the second largest industry after textile. The remaining production is retained for seed purpose or dispose-off by making gur (raw sugar) (Ahmad et al., 1991; Rehman et al., 1992; Shaheen, 2007).

$\mathrm{Bi}$ products such as paper, molasses ethanol and organic fertilizer, are also obtained from sugarcane. Sugarcane production at national level was 62.65 million tonnes from an area of 1.14 million hectares; however, both acreage and production fluctuate frequently (GOP, 2015).

Sugarcane is equally popular in Khyber Pakhtunkhwa (KP) among small holder and large scale commercial farming sectors. KP contribute 10.66 percent in total sugarcane production at national level and out of total share 8.33 percent area (GOP, 2015). In Khyber Pakhtunkhwa (KP) the supply of sugarcane to mills depends on gur and sugarcane prices and seed requirement. Seed requirement is quite high, depending upon variety $1 / 8$ of the area is retained for planting as a seed. sugarcane production is still labor intensive because of exercising the traditional methods. Growers apply traditional methods of production which are mostly labor intensive and cause pre and post-harvest losses (Nazir et al., 2013).

Table 1 shows that per unit yield of sugarcane crop is lowest in KP compare to other provinces. Low yield limits investment opportunities and saving of farming community.

Table 1: Provincial yield of sugarcane in Pakistan (tonnes/hectare).

$\begin{array}{llll}\text { Year } & \text { Punjab } & \text { Sindh } & \text { Khyber Pakhtunkhwa } \\ 2009-10 & 51.60 & 57.70 & 44.70 \\ 2010-11 & 55.75 & 60.43 & 45.59 \\ 2011-12 & 56.34 & 59.00 & 45.82 \\ 2012-13 & 56.00 & 63.00 & 44.70 \\ 2013-14 & 54.00 & 59.00 & 45.00\end{array}$

Source: Pakistan Sugar Mills Association, Annual Report, 2014.

In several previous studies conducted in KP (i.e Asif et al. (2005), Nazir et al. (2013) and Rehman et al, (2012) the agronomic aspects of sugarcane crop has been considered. Also in a number of studies Ali and
Chaudhary (1990), Ali et al. (2013) and Ali and Jan (2017) technical efficiency in sugarcane production has been measured, but exclusively confined to individual district or region level.

Reference to Pakistan, several previous studies has reported larger population reliance on farm income. Therefore, enhancing farm productivity and efficiency would enable farmers to get a position of higher level of income, will help to fill demand and supply gap and food shortage (Fatima et al., 2016). Quantitative analysis of productivity and discovering key determinants of farm technical efficiency is utmost necessary for policies and management. According to Belbase and Grabowski (1985) productivity is more important than new technology if farmers are not using the existing one efficiently.

Quantification of technical efficiency provide inputs to planners, growers and other's stake holders concerned. Sugarcane production is a job provider activity, therefore, growers performance and reasons of low yield across the province need to be investigated. In order to realize these objectives, this study was designed with main aim, to estimate technical efficiency of sugarcane growers and to identify its main determinants.

\section{Materials and Methods}

\section{Study area}

Ecologically Khyber Pakhtunkhwa (KP) is divided into Northern, central and the southern regions. Climate in north is normal, moderate in center while sever in south (Figure 1) (Samreen and Amin, 2012). Crop under study is grown in central, southern and lower northern region. In order to represent entire province survey was conducted in three districts of Khyber Pakhtunkhwa (KPK) (Malakand form north, Charsadda from central and D.I. Khan from southern region).

\section{Sampling and data collection}

This study was based on primary data, collected from sugarcane growers in KP during crop season 2015, using a well-structured questionnaire. As Battese et al. (1996) highlighted that questionnaire is an ordered list of questions for a survey. In survey numeric data about key practices in production and inputs utilization was focused. Population for current study are all sugarcane growers in these three districts. 
Randomly through multistage sampling technique 300 sugarcane growers were interviewed in these three districts.

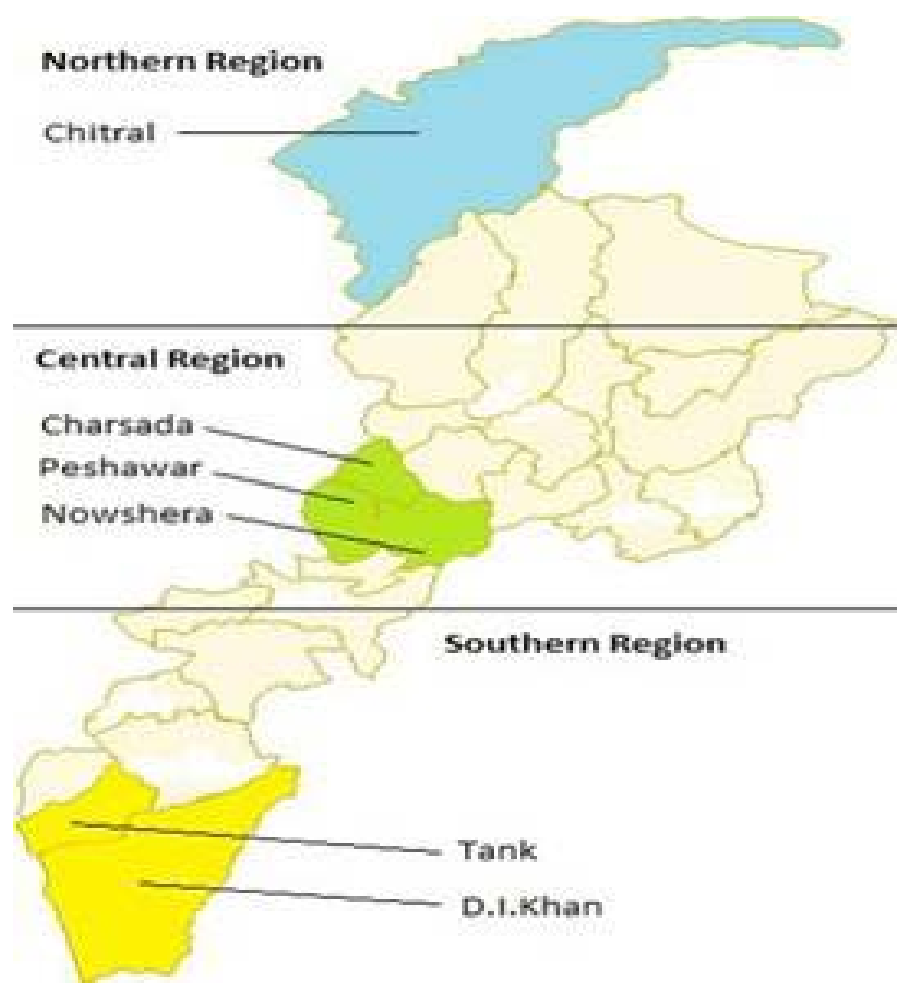

Figure 1: Khyber Pakhtunkhwa three climatic zones.

Sources: Khyber Pakbtunkhwa maps (2012).

\section{Analysis of technical efficiency}

Prior literature reveals that research article by Farrell (1957) paved the way for efficiency and productivity analysis. Fundamentally two approaches have been used in efficiency analysis, one is parametric based on Stochastic Frontier Analysis (SFA) and proposed by Aigner et al. (1977) and Meeusen and Ven Den Broke (1977). Second one is non-parametric, known as Data Envelopment Analysis (DEA), proposed by Charness et al. (1978).

Technical efficiency represents a firm's ability to produce maximum possible level of output at a given technology. Quantitatively it ranges from zero to one. A value different from unity reflects extent of technical inefficiency while a score of unity means technically efficient performance. According to Muller (1974) inefficiency arise due to grower's socio-economic characteristics but little is known about it.

Because of taking into account the stochastic noise SFA is convenient in agricultural sector. Therefore, in present study, the Stochastic Frontier Analysis (SFA) is used to measure technical efficiency accessible from a specific bundle of inputs and technology. Formally,
$Y=f\left(X_{i}\right) \varepsilon_{i}$

Where;

$\mathrm{X}$, represents the independent variables and $\varepsilon_{i}$ is the error term. According to Aigner et al. (1977) the error term is decomposed into two components i.e. $\varepsilon_{i}=\mathrm{V}_{i}-$ $\mu_{i}$ Where $v_{i}$ represent a symmetric component, that capture factors beyond the control of the producer such as droughts, floods etc. It is assumed to be independently and identically distributed as $\mathrm{N}(0$, $\sigma_{v}^{2}$ ). The term $\mu_{i}$ is assumed, one sided, account for inefficiency in outputs and mainly associated with socio-economic characteristics of grower's. According to Battese and Broca, 1997 " $\mu_{i}$ " is positive, half normal and imitates that each producer lie on or below its frontier.

When $\mathrm{Y}_{i}$ represent observed yield of $\mathrm{i}^{\text {th }}$ farmer and $\mathrm{Y}^{*}{ }_{\mathrm{i}}$ the maximum possible output or frontier yield for $\mathrm{i}^{\text {th }}$ farmer, than

$$
\begin{gathered}
T E_{i}=\frac{Y_{i}}{Y_{i}^{*}} \quad \ldots(2) \\
=\exp \left(X_{i}, \beta+V_{i}-\mu_{i}=\exp \left(-\mu_{i}\right)\right.
\end{gathered}
$$

The associated technical inefficiency effect was defined by Battese and Coelli (1995) as under:

$$
U_{i}=\delta_{0}+\delta_{i} Z_{j}+\omega_{i}
$$

Where;

$\mathrm{Z}_{i}$ represents explanatory variables associated with technical inefficiency, $\delta$ represents unknown parameters to be estimated and $\omega_{i}$ encompass unobservable random variables.

\section{Stochastic production frontier model}

In current study, parametric approach under the formulation of Cobb-Douglas production function was applied, whose general form is given below:

$$
\operatorname{Ln} Y=\beta_{0}+\sum_{i=1}^{n=9} \beta_{i} \ln x_{i}+\varepsilon
$$

Where;

$Y_{i}=$ farm output $(\mathrm{kg}) ; X_{1}=$ Farm size; $X_{2}=$ Labor man days; $X_{3}=$ Seed; $X_{4}=$ Tractor hours; $X_{5}=$ irrigation; $X_{6}=$ Urea; $X_{7}=$ DAP; $X_{8}=$ Farmyard manure; $X_{9}$. Pesticides; $\varepsilon=v_{i}-\mu_{i}=$ compound error term. The terms $\beta_{0}$ and $\beta_{i}$ are intercept and parameters to be estimated respectively. 
Technical inefficiency estimation

It is implicit that not all farmers produce on the frontier some lie or produce below the frontier, thus represent inefficiency. For policy recommendations both measurement and identification of factors that lead to inefficiency are necessary to consider. In view of this, in-efficiency was modeled as follow:

$$
\mu_{i}=\delta_{0}+\sum_{i=1}^{6} \delta_{i} Z_{j}+\omega_{i}
$$

Where;

$\mu_{i}$ is inefficiency effect; $Z_{1 i}$ to $Z_{6 \mathrm{i}}$ represents socio economic characteristics of respondent's such as grower's age, formal years of schooling, household size, off-farm income, contacts with extension agents and tenurial status. $\omega_{i}$ is random error and $\delta_{0}$ and $\delta_{i}$ are intercept and unknown parameters.

Following Rahman and Rehman (2008) and Coelli and Battese (1996) estimates for all the parameters in Equation 2, 3 and 4 are estimated jointly by the method of maximum likelihood, using computer program STARTA.

\section{Results and Discussion}

Descriptive statistics presented in Table 1 helps to arrange data in a practical way. It shows average application of inputs, farm size and average yield. It is evident that average sugarcane yield per annum was $24319.72 \mathrm{~kg} \mathrm{acre}^{-1}$ under the average farm size of 2.21 acres in study area. Labor share constitute a mean of 48.76 man days, which indicate that sugarcane production is labor intensive in study area. Average seed rate $2413.04 \mathrm{~kg}$ indicate that sufficient quantity of produce need to be retained for plantation. Average numbers of irrigation (17.00) applied were found less than recommended numbers (25 per annum), which tend to effect output and grower's income. Regarding less numbers of irrigation Loony (1999) reported that it decrease the effectiveness of other inputs. For field operation on average tractor use arrived at 19.62 hours. In study area average consumption of fertilizer was $129.39 \mathrm{~kg}$ for urea, $82.03 \mathrm{~kg}$ for DAP and 1713.55 $\mathrm{kgs}$ for farmyard manure. Standard deviation shows dissimilarity if the rate of application. Per annum average pesticides (3327.03 milliliter) shows that in sugarcane crop its use is comparatively low.

Where; DAP stands for Chemical fertilizer Diammonium phosphate, FYM stands for Farmyard manure, $\mathrm{ML}=$ milliliter. No. $=$ Number, $\mathrm{Kg}=$ Kilogram, $\mathrm{SD}=$ Standard Deviation

Table 2: Summary statistics for important variables.

$\begin{array}{llll}\begin{array}{l}\text { Variables } \\ \text { Production } \\ \text { variables }\end{array} & \text { Description } & \text { Mean } & \text { SD } \\ \mathrm{Y} & \text { Sugarcane Yield (Kg) } & 24319.72 & 2557.27 \\ \mathrm{X}_{1} & \text { Farm size (acre) } & 2.21 & 1.01 \\ \mathrm{X}_{2} & \text { Hired labor (man days) } & 48.76 & 7.78 \\ \mathrm{X}_{3} & \text { Seed (kg) } & 2413.04 & 687.32 \\ \mathrm{X}_{4} & \text { Tractor (hours) } & 19.62 & 3.87 \\ \mathrm{X}_{5} & \text { Irrigation (No.) } & 17.00 & 3.17 \\ \mathrm{X}_{6} & \text { Urea (kg) } & 129.39 & 49.91 \\ \mathrm{X}_{7} & \text { DAP (kg) } & 82.03 & 18.05 \\ \mathrm{X}_{8} & \text { Fym (kg) } & 1713.55 & 748.43 \\ \mathrm{X}_{9} & \text { Pesticides (ml) } & 3327.03 & 3475.96\end{array}$

Source: Field Survey, 2015.

\section{Production analysis}

Based on the model discussed in the previous section the results are presented in Table 2 . Results revealed that coefficients for area $\left(\mathrm{X}_{1}\right)$, labor $\left(\mathrm{X}_{2}\right)$, seed $\left(\mathrm{X}_{3}\right)$, tractor hours $\left(\mathrm{X}_{4}\right)$, irrigation $\left(\mathrm{X}_{5}\right)$ and urea $\left(\mathrm{X}_{6}\right)$ are positive and significant at $5 \%$ level, which mean that one percent change in these variables might increase sugarcane yield equal to coefficients associated with these variables. Moreover, the coefficient for $\operatorname{DAP}\left(\mathrm{X}_{7}\right)$, Farmyard manure $(\mathrm{FYM})\left(\mathrm{X}_{8}\right)$ and pesticides $\left(\mathrm{X}_{9}\right)$ are non-significant but carry positive sign. Major reason might be underutilization of these inputs in study area.

Farm levels technical efficiency and inefficiency analysis Technical inefficiency model results added in Table 2 revealed that age (age was used as a proxy for experience) carry negative signs and is significant at $5 \%$ level, which means that compare to younger sugarcane growers, because of practical know how, aged farmers are technically more efficient. The findings were supported by Padilla et al. (2001) and Coelli and Battese (1996).

The negative contribution of educational level to technical efficiency was noted in the study area. Results shows growers who has spent more years in formal education tends to be less efficient. Traditional production methods and trends of educated growers to search off-farm income opportunities were the obvious reasons. Musaba and Bwacha (2014) and Wang et al. (1996) has also reported similar results in 
their research study.

Table 3: Production function estimates for sugarcane crop in study area.

$\begin{array}{lllll}\text { Variables } & \begin{array}{l}\text { Param- } \\ \text { eter }\end{array} & \begin{array}{l}\text { Coeffi- } \\ \text { cients }\end{array} & \begin{array}{l}\text { T- } \\ \text { ratio }\end{array} & \begin{array}{l}\text { P- } \\ \text { value }\end{array} \\ \text { Production function } & & & & \\ \text { Constant } & \beta_{0} & 4.353 & 29.06 & 0.000 \\ \text { Farm size }\left(\mathrm{X}_{1}\right) & \beta_{1} & 0.022 & 3.67 & 0.000 \\ \text { Labor }\left(\mathrm{X}_{2}\right) & \beta_{2} & 0.073 & 3.19 & 0.000 \\ \text { Seed }\left(\mathrm{X}_{3}\right) & \beta_{3} & 0.136 & 5.11 & 0.000 \\ \text { Tractor hours }\left(\mathrm{X}_{4}\right) & \beta_{4} & 0.041 & 3.21 & 0.000 \\ \text { Irrigation }\left(\mathrm{X}_{5}\right) & \beta_{5} & 0.072 & 4.89 & 0.000 \\ \text { Urea }\left(\mathrm{X}_{6}\right) & \beta_{6} & 0.081 & 5.51 & 0.000 \\ \text { DAP }\left(\mathrm{X}_{7}\right) & \beta_{7} & 0.01 & 1.76 & 0.075 \\ \text { FYM }\left(\mathrm{X}_{8}\right) & \beta_{8} & 0.021 & 1.52 & 0.051 \\ \text { Pesticides }\left(\mathrm{X}_{9}\right) & \beta_{9} & 0.004 & 1.11 & 0.049 \\ \text { Inefficiency model } & & & & \\ \text { Constant } & \delta_{0} & -3.71 & -3.04 & 0.023 \\ \text { Age }\left(\mathrm{Z}_{1}\right) & \delta_{1} & -0.168 & -4.03 & 0.006 \\ \text { Education }\left(\mathrm{Z}_{3}\right) & \delta_{3} & 0.782 & 3.51 & 0.004 \\ \text { Family size }\left(\mathrm{Z}_{4}\right) & \delta_{4} & -0.071 & -1.29 & 0.310 \\ \text { Off farm income }\left(\mathrm{Z}_{5}\right) & \delta_{5} & -0.624 & -2.24 & 0.011 \\ \text { FHD }\left(\mathrm{Z}_{6}\right) & \delta_{6} & -0.003 & -0.4 & 0.549 \\ \text { Extension contacts }\left(\mathrm{Z}_{7}\right) & \delta_{7} & -0.039 & -1.09 & 0.103 \\ \text { Tenural status }\left(\mathrm{Z}_{8}\right) & \delta_{8} & 0.031 & 0.12 & 0.491 \\ \text { Variance Parameter } & & & & \\ \text { Sigma Square } & & & & 0.00153 \\ \text { Gamma } & & & & 0.59 \\ \text { Go } & & & & \\ & & & & \end{array}$

Source: Self calculation of Study results.

Negative and significant coefficient of off-farm income suggest that growers having off farm income opportunities are technical more efficient. Off farm income enable farmer's to make available the essential inputs on time. Results are consistent with Tesfay et al. (2005) and Pascaul (2005).

It was found that family size not contribute in technical efficiency. Large family size having maximum members below the age of ten years divert financial resources to their health and education.

Being a key policy instrument, increased sugarcane production need to be related to extension services but in study area its impact was found statistically non-significant. Possible reasons were weak linkage of extension workers with farming community, traditional methods of sugarcane production, topdown approach and trend of growers to prefer off farm activities. The findings has been supported by Feder et al. (2003) and Zinnah et al. (1993).

The coefficient for land tenure is positive and nonsignificant, main reason realized during survey was share cropping system, which discouraged investment. Results reported by Gavian and Ehui (1999), Ali (2009), Oladela et al. (2011) and Abdulai et al. (2011) also depict decreased efficiency under share cropping system and increased under fixed land rent system.

Variables considered for production function and inefficiency model has been mostly used in previous studies. These variables were also justified by factual circumstances prevailed in the field. Gamma value, which indicate variation in production due to inefficiency arrived at 0.59 , which mean that $59 \%$ variation in sugarcane production is inefficiency, while the rest $41 \%$ might represent random noise.

Table 3 shows average technical efficiency of sugarcane farms in study area is $70 \%$ with range from minimum 53 to maximum 98\%. In a similar study, Heman et al. (2011) reported 75\% average technical efficiency for sugarcane farms in Pakistan. Distribution in the technical efficiency reveals that $48.49 \%$ of sample respondents have had TE index below the mean value, while remaining are above TE mean. Only 7.69 $\%$ sugarcane growers had technical efficiency level above $90 \%$. Analysis shows that average grower could realize $28 \%$ yield gains to achieve maximum technical efficiency level (98\%) of fellow efficient grower's.

Table 4: Frequency distribution and mean index of technical efficiency.

$\begin{array}{lll}\text { Frequency level } & \text { No. } & \text { \% } \\ <0.50 & 19 & 6.35 \\ 0.50-0.70 & 145 & 48.49 \\ 0.70-0.80 & 61 & 20.40 \\ 0.80-0.90 & 51 & 17.05 \\ >0.90 & 23 & 7.69 \\ \text { Mean } & 0.70 & \\ \text { Min } & 0.53 & \\ \text { Max } & 0.98 & \end{array}$

Source: Study results and self-calculation.

\section{Conclusions and Recommendations}

In current study technical efficiency of sugarcane crop was calculated in districts Malakand, D. I. Khan and Charsadda of Khyber Pakhtunkhwa. To achieve June 2020 | Volume 36 | Issue 2 | Page 503 
the set objectives a sample of 299 sugarcane growers were interviewed for inputs and output data. CobbDouglas type production function was estimated by maximum likelihood method. Findings of the study reveals that mean technical efficiency index is $70 \%$, ranging from minimum 53 to maximum 98\%. Maximum farmers are operating below mean technical efficiency level. Results also show that average grower is producing $28 \%$ less than potential yield of the efficient fellow grower. It is found that grower's age, experience and off-farm income are negatively correlated with technical inefficiency. Formal education of sample respondents exhibit positive relationship with technical inefficiency. In others socio-economic variables household size, distance for home to farm and contacts with extension agents were non-significant with negative signs. Tenure status was non-significant with positive coefficient. Priority implication of the study is that experience and off-farm income has the potential to increase technical efficiency are the policy variables. Output price based on cost of production and timely payment to growers might keep experience growers in sugarcane production. Similarly, improvement in extension services would help to convince growers on adopting new production techniques that will help to increase productivity.

\section{Novelty Statement}

Considering cost of sugarcase production while fixing its price might increase productivity and technical efficiency. It will also work as an incentive to keep experienced growers involved in its production.

\section{Author's Contribution}

Amjad Ali: Initial survey and draft writing.

Lal Almas: Technical assistance, overview of final draft and rectification accordingly.

Syed Attaullah Shah: helped ub model fitting anf econometric analysis.

Hina Fatima: Check the consistency of results with other similar studies.

Asim Khan: Helped in surbey data pubching and analysis.

\section{References}

Abdulai, A., V. Owusu and R. Goetz. 2011. Land tenure differences and investment in land improvement measures: theoretical and empirical analyses. J. Dev. Econ. 96(1): 66-78. https://doi.org/10.1016/j.jdeveco.2010.08.002

Ahmad, R., M. Saleem and M.S.S. Nazir. 1991. Autumn rationing potential of five sugarcane varieties. Pak. J. Agric. Res. 13: 26-29.

Aigner, D.J., C.A.K. Lovell and P. Schmidt. 1977. Formulation and estimation of stochastic production function models. J. Econ. 6: 21-37. https://doi.org/10.1016/0304-4076(77)90052-5

Ali, A. and A.U. Jan. 2017. Analysis of technical efficiency of sugarcane crop in Khyber Pakhtunkhwa. A stochastic frontier Approach. Sarhad J. Agric. 33(1): 69-79. https://doi. org/10.17582/journal.sja/2017.33.1.69.79

Ali, M.J., G.A. Jariko and A. Nazir. 2013. Factors affecting sugarcane production in Pakistan. Pak. J. Commerce Soc. Sci., 7(1): 128-140.

Ali, W. 2009. The effect of land tenure on the productivity of tomato farmers in the Offinso North District of Ashanti Region, Ghana. College of Agriculture and Natural Resources. Faculty of Agriculture, Department of Agricultural Economics, Agribusiness and Extension, KNUST. Kumasi, Ghana.

Ali, F., 1986. Time series analysis of economics of production of sugarcane. Public. No. 182, IDS, NWFP Agric. Univ. Peshawar, Pakistan.

Ali, M. and M.A. Chaudhary. 1990. Inter-regional farm efficiency in Pakistan's Punjab: A frontier production function study.J.Agric. Econ.41:6274. https://doi.org/10.1111/j.1477-9552.1990. tb00619.x

Annual Report of Trading Corporation of Pakistan (pvt) Limited (ACTP). 2001-2002. Ministry of Commerce, Govertment of Pakistan.

Asif, N., M. Ishaq and K. Jehangir. 2005. Sugar policy analysis: A case study of Charsadda and Mardan Districts. Sarhad J. Agric. 21(3): 499502.

Battese, G.E. and S.S. Broca. 1997. Functional forms of stochastic frontier production functions and models for technical efficiency effects: A comparative study for wheat farmers in Pakistan. J. Prod. Anal. 8: 395-414.

Battese, G.E., S.J. Malik and M.A. Gill. 1996. An investigation of technical inefficiencies of production of wheat farmers in four districts of Pakistan. J. Agric. Econ. 47: 37-49. https://doi. org/10.1111/j.1477-9552.1996.tb00670.x

Battese, G.E. and T.J. Coelli. 1995. A model for 
technical inefficiency effects in a stochastic frontier production function for panel data. Emp. Econ. 20: 325-32.

Belbase, K. and R. Grabowski. 1985. Technical efficiency in Nepalese Agriculture. J. Develop. Areas, 19: 515-25.

Charnes, A., W.W. Cooper and E. Rhodes. 1978. Measuring the inefficiency of decision making unit. Eur. J. Oper. Res. 2: 429-444. https://doi. org/10.1016/0377-2217(78)90138-8

Coelli, T.J. and G.E. Bettese. 1996. Identifications of factors which influence the technical inefficiency of Indian farmers. Aust. J. Agric. Econ. 40(2): 103-128. https://doi. org/10.1111/j.1467-8489.1996.tb00558.x

Farrell, M.J., 1957. The measurement of productive efficiency. J. R. Stat. Soc. Ser. A, 120: 253-290. https://doi.org/10.2307/2343100

Fatima, H., T. Mukhtar and N. Bader, 2016. Farm specific determinants of farm income and efficiency in Pakistan: A parametric analysis. J. Agric. Res. 54(4): 813-825: ISSN: 2076-7897. www. Jar.com.Pk

Feder, G., R. Murgai and J.B. Quizon. 2004. Sending farmers back to school: the impact of farmer field schools in Indonesia. Rev. Agric. Econ. 26(1): 45-62. https://doi.org/10.1111/ j.1467-9353.2003.00161.x

Gavian, S. and S. Ehui. 1999. Measuring the productive efficiency of alternative land tenure contracts in a mixed crop-livestock system in Ethiopia. Agric. Econ. 20: 37-40.

GoP. 2015. Economic survey of Pakistan 2015-16. Finance Division Economic Advisor's Wing, Islamabad.

GoKP. Crop statistics, 2013-14.

Green, W.H., 1980. On the estimation of a flexible frontier production model.J. Econ. 13: 101-116. https://doi.org/10.1016/0304-4076(80)900457

Heman, D.L., A. Nazir and A.M. Khushk, 2011. Technical, allocative and economic efficiencies in sugarcane production in Pakistan: A nonparametric approach. Bus. Rev., 6: 131-143.

Hussain M.F., S. Anwar and Z. Hussain. 2006. Economics of sugarcane production in Pakistan: A Price Risk Analysis. Int. J. Finance Econ. 4(2006).

Hussain,M.,Z.Hussain and M.Ashfaq.2004.Land and water productivity in Pothwar Plateau. Pak. J. Water Resour. 8(2): 43-48.
Hussain, S.S., 1989. Analysis of economic efficiency in Northern Pakistan: Estimation, causes and nd policy implication. Ph.D dissertation, University of Illinions, Urbana-Champaign.

Looney, R.E. 1994. Profile of regional efficiency in Pakistan: Comparison of public and private sector manufacturing firms. Publ. Enterp., 14: 446-467.

Looney, R.E. 1999. Private sector investment in Pakistan Agriculture: The role of infrastructure investment. Journal of Developing Sciences. 15(2) p 190-203

Mceusen, W. and J.van den Broeck.1977.Efficiency estimation from Cobb-Douglas production function with composed error. Int. Econ. Rev. 18: 435-44.

Muller, J., 1974. On sources of measured technical efficiency: the impact of information. Am. J. Agric. Econ., 56: 730-738. https://doi. org/10.2307/1239302

Musaba, E. and I. Bwacha. 2014. Technical efficiency of small scale maize production in Masaiti District, Zambia: A stochastic frontier approach. J. Econ. Sustainable Dev., 5(4): 104111.

Nazir, A.G., A. Jariko and M.A. Junejo. 2013. Factors affecting sugarcane production in Pakistan. Pak. J. Commerce Soc. Sci., 7(1): 128140.

Oladele, O.I., A. Kolawole and T. Wakatsuki. 2011. Land tenure, investment and adoption of Sawah rice production technology in Nigeria and Ghana: A qualitative approach. Afr. J. Agric. Res. 6(6): 1519-1524.

Padilla-Fernandez M.D. and P. Nuthall. 2001. Farmers' goals and efficiency in the production of sugar cane: The Philippine case, Farm and Horticultural Management Group Lincoln University,ISSN 1174-8796, Res. Rep.07/2001.

Pascual, U., 2005. Land use intensification potential in slash-and -burn farming through improvements in technical efficiency. Ecol. Econ. 52: 497-511. https://doi.org/10.1016/j. ecolecon.2004.09.012

PSMA. 2013-14. Pakistan sugar mills association annual report.

Rehman, S., G.S. Khan and I. Khan. 1992. Coordinated uniform national varietal trial on sugarcane. Pak. J. Agric. Res. 13: 136-140.

Rahman, S. and M. Rahman. 2008. Impact of land fragmentation and resource ownership 
on productivity and efficiency: the case of rice producers in Bangldish, Land Use policy. 2: 95-103. https://doi.org/10.1016/j. landusepol.2008.01.003

Rehman, U.N., J. Khan and M. Tariq. 2012. The impact of education on agriculture production in Khyber Pakhtunkhwa province (1975-2008). Sarhad J. Agric. 28(2): 345-352.

Rizvi,J.A.,2000. Causes of sugar industry's sickness. Economics and industrial publication. Econ. Rev. Volume 31.

Samreen, B. and A. Amin. 2012. Empirical assessment of region specific climate impact on crops production in Khyber Pakhtunkhwa, Pakistan. Res. J. Area Study Center, Univ. Peshawar-Pakistan. 51(4): 261-276.

Shaheen, R.K., 2007. Viewing biofuel (Ethanol) prospects in Pakistan through a sustainable dev elopment prism. SDPI Res. News Bull. 14(3).

Scott, E.W., K.A. Siddiqi, A.S. William and I.M. Muhammad. 1990. Export restrictions- A study of restrictions on agricultural exports in
Pakistan. Special Report No. 17, Ministry of Food, Agric. \& Coop. and US Agency for Int'1. Dev. Islamabad

Tayyab, M., 1972. Price movements of agricultural commodities in Peshawar. Pub. No. 67, Board of Econ. Enquiry. Univ. Peshawar, Pakistan.

Tesfay, G., R. Ruben. J. Pender and A. Kuyvenhoven. 2005. Resource use efficiency on own and sharecropped plots in Northern Ethiopia: Determinants and implications for sustainability.

Wang, J., G.L. Cramer and E.J. Wailes. 1996. Production efficiency in Chinese agriculture: evidence from Rural Household Survey data. Agric. Econ. 15: 17-28. https://doi. org/10.1111/j.1574-0862.1996.tb00417.x

Zinnah, M.M., J.L. Compton and A.A. Adesina. 1993. Research-extension-farmer linkages within the context of the generation, transfer and adoption of improved mangrove swamp rice technology in West Africa. J. Int. Agric. 32: 201-211. 